\title{
ESTRUTURA EM VILLA-LOBOS: UMA ANÁLISE DO PRELÚDIO DAS BACHIANAS BRASILEIRAS NR. IV ${ }^{1}$
}

\author{
Acácio Tadeu de Camargo Piedade ${ }^{2}$ \\ Gabriel Moreira ${ }^{3}$
}

RESUMO: Neste artigo pretende-se analisar o conhecido prelúdio das Bachianas Brasileiras $\mathrm{n}^{\mathrm{o}}$ IV em busca de coerência estrutural. O objetivo é, através de reduções schenkerianas, avaliar o que a peça traz em termos de estrutura profunda, e em que termos esta dimensão pode dialogar com aspectos mais salientes de Villa-Lobos.

PALAVRAS-CHAVE: Análise Musical; Musicologia-Etnomusicologia; Teoria musical; Música no contexto sócio-cultural e histórico.

\section{Introdução}

Não há dúvida que Villa-Lobos tenha sido influenciado por Bach. A remissão a Bach é óbvia já pelo nome deste ciclo, "Bachianas". É igualmente certo que o atributo "Brasileiras" aponta para a presença de elementos de "brasilidade" na obra. Mas até que ponto esta influência de Bach e este esforço de brasilidade se evidenciam no Prelúdio da Bachiana Brasileira $n^{\circ} 4$ ? Seria possível constatar estes elementos no plano melódico, harmônico, contrapontístico e estrutural da peça em questão? Com o objetivo de responder estas perguntas, realizaremos uma análise da peça empregando ferramentas schenkerianas (SCHENKER, 1979; SALZER, 1962; SALZER \& SCHACHTER, 1969; CADWALLADER \& GAGNÉ, 1988, 2006). A análise tornará explícito o contraponto que estrutura a condução das vozes da peça, bem como a harmonia e a estrutura das frases, o que nos permitirá refletir sobre a inter-relação destes elementos tanto com a linguagem bachiana de Villa-Lobos quanto com sua brasilidade. A análise rítmico-motívica também será muito útil para clarear onde elementos da música brasileira se fazem presentes (choro, maxixe, samba), em interação com outros motivos melódicos inspirados pela música de Bach.

Abordaremos inicialmente o contexto histórico e musical em que se encontrava Villa-

1 Projeto de pesquisa "Estudos em análise musical e musicologia: da estrutura do texto musical ao contexto sócio-cultural e histórico".

2 Orientador. Departamento de Música.

3 Bolsista PROBIC. 
Lobos ao iniciar a composição das Bachianas Brasileiras. Para isso partiremos tanto da própria relação de Villa-Lobos com a música de Bach, como um compositor do modernismo e como que novas tendências da música do início do século XX propiciaram o pano de fundo para a composição dessa obra.

\section{Villa-Lobos e J. S. Bach}

Em diversos livros e biografias sobre Villa-Lobos, é destacada a influência que a música de Bach exerceu na infância do compositor brasileiro. Os saraus noturnos que seu pai promovia em sua casa com membros da Sociedade de Concertos Sinfônicos do Rio de Janeiro (que ele mesmo havia fundado) eram momentos nos quais Heitor se deleitava, ouvindo música. Silva (2003) afirma que "nas noites de música que o professor Raul promovia em sua casa, Villa-Lobos conseguia escapulir do leito, sem ser notado pela mãe e aproximar-se da sala onde o pai e os amigos tocavam" (op.cit, p.41).

A música de Bach, portanto, era tocada nas "noitadas musicais" que o sr. Raul VillaLobos, pai de Heitor, promovia em sua casa. Silva (2003) apresenta um diálogo do futuro compositor com sua mãe em uma destas ocasiões:

“-Mãe, que música era aquela que parecia encantada?

-Bach.

-Quem é Bach?

-Foi um grande compositor que viveu há muitos anos.

-Já morreu? Então ele está no céu? [...] Pois um dia, no céu da música vou me encontrar com Bach.” (SILVA, 2003, p.42)

Ainda conforme Silva (2003), quando Raul Villa-Lobos construiu um protótipo de violoncelo para seu filho e perguntar-lhe se estava contente com o instrumento, Heitor respondeu: "Pai, quando eu crescer eu vou fazer uma música como a daquele que se chama [...] Bach." (op. cit, p. 42).

Mais tarde, segundo o biógrafo e amigo de Villa-Lobos, C. Paula Barros (1950), VillaLobos afirmou ter encontrado na música do sertão melodias semelhantes, em estilo, a algumas das obras de Bach, o que também o projeta para uma composição brasileira com um sotaque bachiano.

"Nas suas Bachianas, por exemplo, sente-se muito das cousas sertanejas. Nessa prodigiosa polifonia que é a $\mathrm{n}^{\circ} 1$, conseguida apenas com oito violoncelos, está nítido o panorama das caatingas, sob o 
galope dos touros bravos e dos vaqueiros. Julgamos que nessa obra mestra do artista, vive o mistério que povoa a alma do sertanejo. Só depois que Villa-Lobos nos contou como havia encontrado esses elementos melódicos à maneira de Bach, em plenos sertões, em meio de vaqueiros e cantadores, foi que compreendemos bem como está adequado esse título de 'Bachianas Brasileiras'" (BARROS,1950, p.36-37)

De fato, esse sotaque pode ser visto nas Bachianas em vários elementos da composição. No momento da composição das Bachianas, Villa-Lobos entrava na fase "neoclássica” (NEVES, 1981), em alguns momentos de suas composições, havia retornado a paradigmas da música da tradição tonal, com o qual se identifica, também, com Bach, como veremos, por exemplo na análise que será feita. Villa-Lobos procurou fazer uma síntese desses dois grupos sonoros, o brasileiro do início do século XX e o de Bach. Não faz citações de melodias de Bach, e se utiliza muito pouco de citações da música popular que se inspirou.

Também é enriquecedor notar a presença da música de Bach em diversos projetos da Superintendência de Educação Musical e Artística (SEMA), organização fundada e presidida por Villa-Lobos no governo de Getúlio Vargas. A música de Bach permeava muitos setores da atuação da SEMA, como concertos públicos e audições da obra de Bach. O próprio VillaLobos declarava sua admiração pela música de Bach, em documentos como Educação Musical (VILLA-LOBOS, 1946).

Segundo LISBOA (2005):

"Para Villa-Lobos, a música de Bach seria 'incontestavelmente a mais sagrada dádiva do mundo artístico' e, por isso, 'sendo tão imensa e

tão profunda, torna-se perigosa a sua divulgação nos meios sociais que não estejam devidamente

iniciados para senti-la' [VILLA-LOBOS,1946, p. 524]. Foi dessa maneira que a SEMA promoveu concertos com repertório bachiano, direcionado principalmente às classes operárias ou, como propôs Villa-Lobos [ib, p. 524], 'obras de J. S. Bach para auditórios incultos'”. (LISBOA, 2005,p.37)

\section{Villa-Lobos e a brasilidade}

Como analisar Villa-Lobos em sua multiplicidade estilística? Para alguns autores, a 
evolução de Villa-Lobos não é contínua, há muitos passos inesperados (PEPPERCORN apud SILVA, 2006). O estilo antropofágico de Villa-Lobos (JARDIM, 2005) talvez seja sua marca maior: digerindo diferentes estilos e produzindo linguagens híbridas, seria Villa-Lobos um pós-moderno avant la lettre ? No início da sua carreira como compositor, Villa-Lobos decidiu aliar-se ao pensamento musical da vanguarda européia da época, que era o dominante no cenário da música erudita carioca. Segundo Gúerios (2003), baseando-se em depoimento do próprio compositor a um biógrafo (MARIZ, 1949:39), as primeiras sinfonias de Villa-Lobos,

“... foram feitas de acordo com as regras postuladas por Vincent D'Indy em seu Cours de Composition Musicale; a estética proposta por D'Indy, adotada pelos professores do Instituto Nacional de Música, era ligada diretamente à de Wagner. Também ligado a estéticas defendidas pelos professores do Instituto estava seu Naufrágio de Kleonicos, poema sinfônico cuja linguagem musical é uma clara emulação dos princípios do pós-romantismo francês de Saint-Saëns. Dessa forma, a aplicação das idéias estéticas de Wagner, D'Indy e Saint-Saëns serviriam como prova da capacidade de VillaLobos enquanto compositor em face do establishment musical carioca." (GÚERIOS, 2003, p.88)

Contudo, após uma viagem à Paris, em 1923, Villa-Lobos se direcionará a uma composição que salientará a brasilidade de melodias e ritmos em suas obras. Gúerios (op.cit.) também nos explica o porquê de uma mudança tão profunda na mente, e conseqüentemente na obra do compositor. Villa-Lobos, bem como a vanguarda da música carioca, espelhava-se na música de Debussy para construir a vanguarda musical do Rio de Janeiro. Contudo, ao visitar Paris, Villa-Lobos encontrou uma outra música de vanguarda predominante, aquela de Erik Satie e compilada por Milhaud, conduzida pelo pensamento de Jean Cocteau. Gúerios (2003) cita uma crítica que Milhaud fez a uma revista parisiense sobre a música de vanguarda brasileira:

"É lamentável que todas as composições de compositores brasileiros, desde as obras sinfônicas ou de música de câmara dos srs. [Alberto] Nepomuceno e [Henrique] Oswald até as sonatas impressionistas do sr. [Oswaldo] Guerra ou as obras orquestrais do sr. Villa-Lobos (um jovem de temperamento robusto, cheio de ousadias), sejam um reflexo das diferentes fases que se sucederam na Europa de Brahms a Debussy e que o elemento nacional não seja expresso de uma maneira mais viva e mais original. A influência do folclore brasileiro, tão rico em ritmos e de uma linha melódica tão particular, se faz sentir raramente nas obras dos compositores cariocas. Quando um tema 
popular ou o ritmo de uma dança é utilizado em uma obra musical, esse elemento indígena é deformado porque o autor o vê através das lentes de Wagner ou de Saint-Saëns, se ele tem sessenta anos, ou através das de Debussy, se ele tem apenas trinta" (MILHAUD apud GUÉRIOS, 2003, p. 95)

Tal recepção áspera da vanguarda artística francesa em relação à música de VillaLobos fez o compositor direcionar sua composição para a construção de música com caráter nacional: "ele deixaria de tentar compor de acordo com as regras estéticas de compositores franceses, tão valorizadas no Brasil, para tentar retratar sua nação musicalmente, um projeto especialmente valorizado na França" (GÚERIOS, 2003, p. 97).

\section{As Bachianas Brasileiras}

"Bachianas Brasileiras" é uma série de nove suítes compostas para vários grupos instrumentais e vocais, entre 1930 e 1945, marcando o início da fase neoclássica do compositor e também da sua fase de influência nacionalista. Cada uma das Bachianas representa uma fusão entre a música folclórica e popular brasileira (especialmente a música que expressa o éthos sertanejo) e o estilo bachiano (AMATO, 2008, p.2). Comentando a origem das Bachianas Brasileiras e o pensamento musical de Villa-Lobos, Chateaubriand (2006) afirma que:

"A série de nove obras escritas entre 1930 e 1945, intitulada 'Bachianas Brasileiras', é outro exemplo da experiência musical folclorista vivida por Heitor Villa-Lobos. O compositor brasileiro buscou uma síntese entre matrizes musicais brasileiras e a estética de Johann Sebastian Bach (1685-1750), que ele considerava imaginativamente 'um fundo folclórico de todas as nações'. Segundo a pesquisadora Ermelinda Paz, referindo-se ao nome dado a esta série musical, o compositor acha analogias entre a invenção musical de Bach e a música popular brasileira, e disso derivou o seu título enigmático para as Bachianas.” (CHATEAUBRIAND, 2006, p.134)

Essa releitura de elementos musicais brasileiros escritos à maneira de Bach, cujo estilo é tomado como universal, também pode ser notada na própria titulação dos movimentos das Bachianas. Todos os movimentos das suítes receberam dois nomes, um “clássico" (prelúdio, fuga, allegro, etc.) e um brasileiro (nomes próprios das obras, registrando situações ou objetos que captam o éthos folclórico brasileiro (P. ex. "O Trenzinho do Caipira" e "O Canto da Nossa Terra”, respectivamente o quarto e o segundo movimento das $\mathrm{n}^{\circ} 2$ ). 


\section{Prelúdio das Bachianas Brasileiras n. ${ }^{\circ} 4$}

Antes de qualquer coisa, é preciso lembrar, com Caldas, que:

"Existem duas versões desta obra, sendo a primeira para piano e a segunda para orquestra. A versão para piano foi composta de 1930 a 1941, estreada em 1939 por José Vieira Brandão. A versão orquestral é de 1941, tendo sua estréia no dia 5 de julho de 1942, pela Orquestra do Teatro Municipal do Rio de Janeiro" (CALDAS,2007,p.58).

A versão que será analisada aqui é a original, para piano. Antes de se iniciar a discussão acerca do background e middleground da obra, o foreground ${ }^{4}$ será apresentado, por meio de uma breve análise motívica, harmônica e rítmica para que o entendimento da música seja o mais completo possível.

Primeiramente, é necessário dizer que este Prelúdio é estabelecido plenamente na tonalidade de si menor, com frases, cadências e modulações que operam na estabilização dessa tonalidade. Esses termos por si só - tonalidade, modulação, cadências - mostram o direcionamento de Villa-Lobos, como compositor de vanguarda, ao neoclassicismo e à música tradicional de Bach, e mesmo à música de pianistas brasileiros como Ernesto Nazareth, semelhanças que serão exploradas mais tarde e em outros parâmetros.

A música é construída como um grande desenvolvimento de um pequeno motivo, apresentado logo no primeiro compasso da peça:

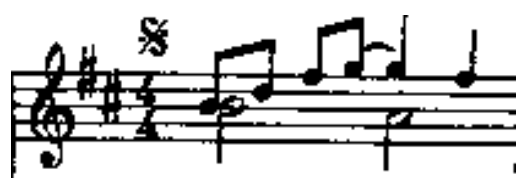

Ilustração 1: motivo principal

do Prelúdio das Bachianas

Brasileiras 4

Esse procedimento, de desenvolver uma composição inteira a partir de um mote apresentado ao início, foi usado magistralmente por Bach, por exemplo, no Prelúdio para a Fuga em Dó maior, no volume I do Cravo Bem Temperado.

4 Os conceitos desenvolvidos por Schenker serão referidos ora em inglês, ora em alemão, e ocasionalmente em português. 


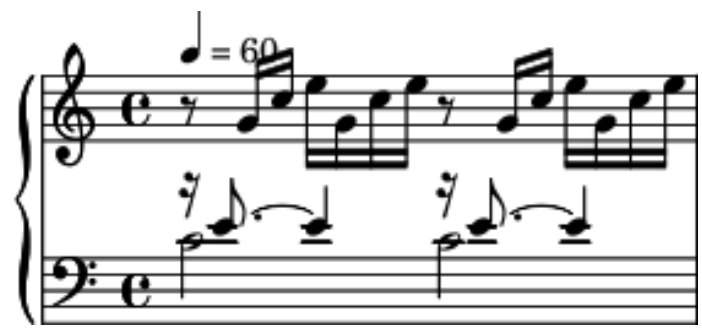

Ilustração 2: motivo principal do Prelúdio da Fuga em Dó maior de Bach

Nestes dois prelúdios, arpejos ascendentes revelam a harmonia implícita e suas vozes internas. A diferença em Villa-Lobos é a presença de uma voz de baixo, freqüentemente dobrada em oitava. As vozes internas são conduzidas por graus conjuntos e seus retardos resolvidos por grau conjunto descendente.

Nesse motivo principal do Prelúdio de Villa-Lobos, o arpejo alcança um retardo que será resolvido no próximo acorde. Geralmente são sétimas resolvendo em sextas ou nonas resolvendo em oitavas (dissonâncias em vermelho e resoluções em verde).

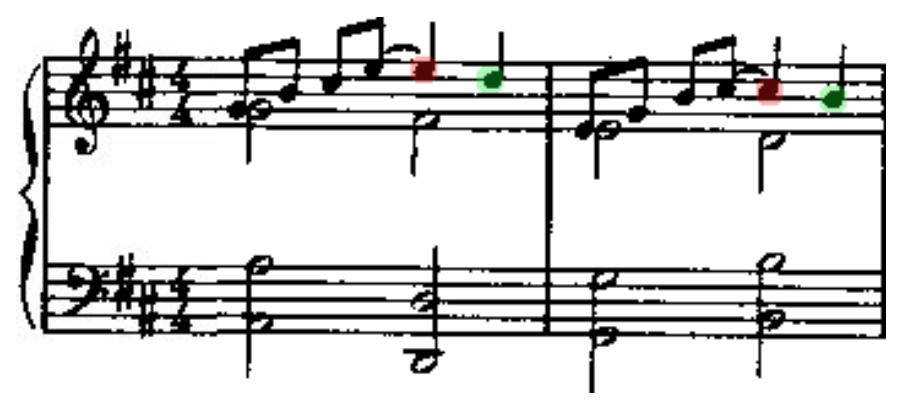

Ilustração 3: compassos 3-4 do Prelúdio

A narrativa da obra é conduzida pelo desenvolvimento do motivo principal. A peça pode ser entendida, no nível fraseológico, como um conjunto de seções que conduzem a melodia ascendentemente ou descendentemente, ou que repetem o motivo melódico, enquanto a harmonia muda pela condução das outras vozes. Esta peça demonstra o intuito de Villa-Lobos em trabalhar o contraponto e a condução das vozes externas em um estilo clássico, típico do barroco. De fato, uma preocupação que remete, mais uma vez, ao estilo de Bach, e que delimita a estrutura da obra como um todo. 
Pensando desta forma, a estrutura formal da peça pode ser esquematizada da seguinte maneira:

\section{Exposição}

-Frase A (c. 1-5) - ascendente - predominantemente movimento contrário com o baixo.

-Frase B (c. 6-9) - repetição do motivo- movimento oblíquo contra o baixo descendente.

-Frase B (c. 10-13) - semelhante à seção anterior, com o baixo uma oitava abaixo.

-Frase A (c.14-18) - com modulação para mi menor, o início do desenvolvimento.

\section{Desenvolvimento}

-seção modulante (c.19-31) - diversas conduções de vozes, mas principalmente sextas paralelas descendentes. (passando por mi menor, fá\# menor, e um desenvolvimento do motivo sobre um ciclo de quartas na harmonia (dominante estendida).

\section{Re-Exposição}

Frase A (c. 33-36) - Melodia exposta no baixo - troca de registro

Coda (c.36-41) - Secção final, misto de elementos das duas frases.

Há muitas influências do romantismo presentes, particularmente na dinâmica e na escrita

pianística: súbitos forte, sforzando, piano, uso de oitavas no baixo e exploração dos diversos registros do piano, fazendo com que muito da expressão de intensidade dessa obra seja produzido pelo espírito dramático do romantismo. Paralelamente, há o uso de padrões típicos do choro, tais como grupos de semínimas e tercinas lembrando o baixo do violão de sete cordas. O grande uso de cromatismos nessas partes também confirma essa relação entre choro e romantismo. 


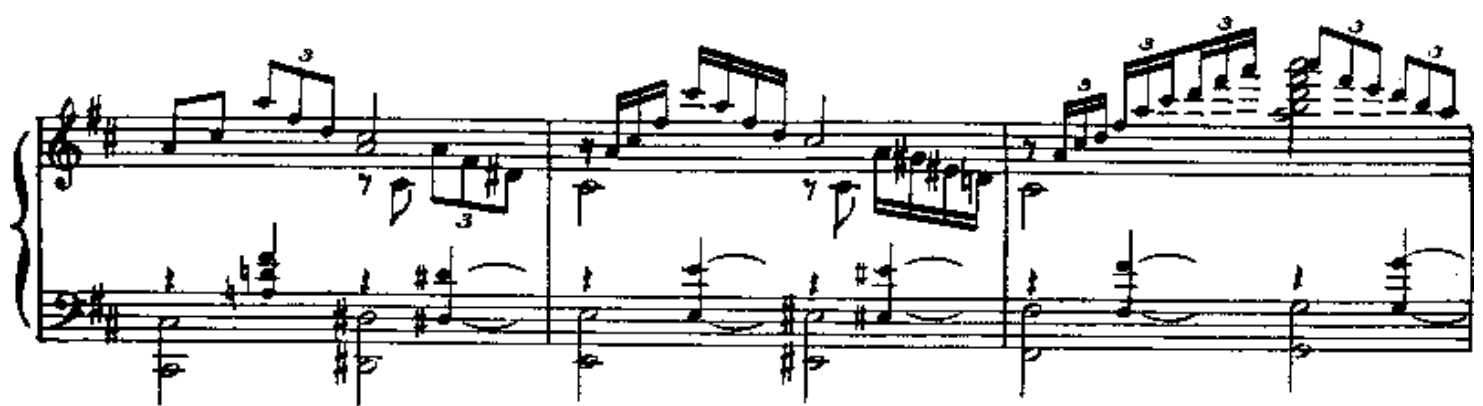

Ilustração 4: Compassos Finais do desenvolvimento (c.28-30) - utilização de motes do vocabulário do choro e romantismo; cromatismos e grande contraste de tessituras

Há ainda, para finalizar essa análise descritiva do Foreground, alguns pontos a serem salientados. O uso de oitavas nas melodias também remete essa obra a influência da música para piano do romantismo e do choro.

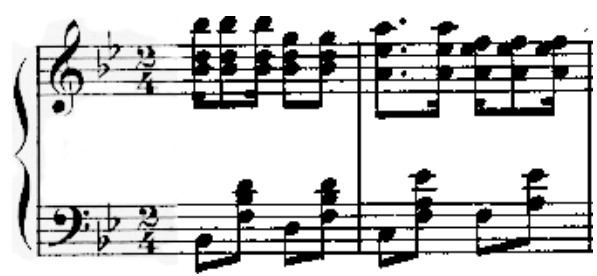

Ilustração 5: Brejero, de Ernesto Nazaré (c.21-22)-uso de oitavas

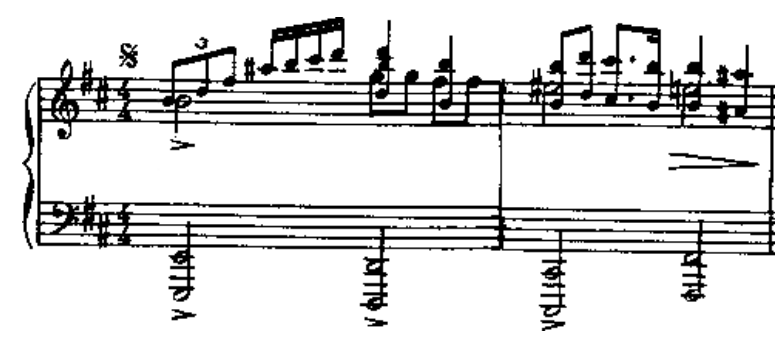

Ilustração 6: Prelúdio de Villa-Lobos (c.12-13)

- Uso de oitavas para enfatizar a melodia

Para melhor compreensão do gráfico que mostrará os prolongamentos e condução de vozes de cada seção do Prelúdio, uma partitura da música segue abaixo, e logo em seguida será apresentado um gráfico do foreground da peça. 
No. 1 from

$$
\text { PRELUDIO - (Introduçāo) }
$$

Bachiznas Brasileiras No. 4

H. VIUA-Loeds

Rin, 1941

EXPOSIÇÃO frase a
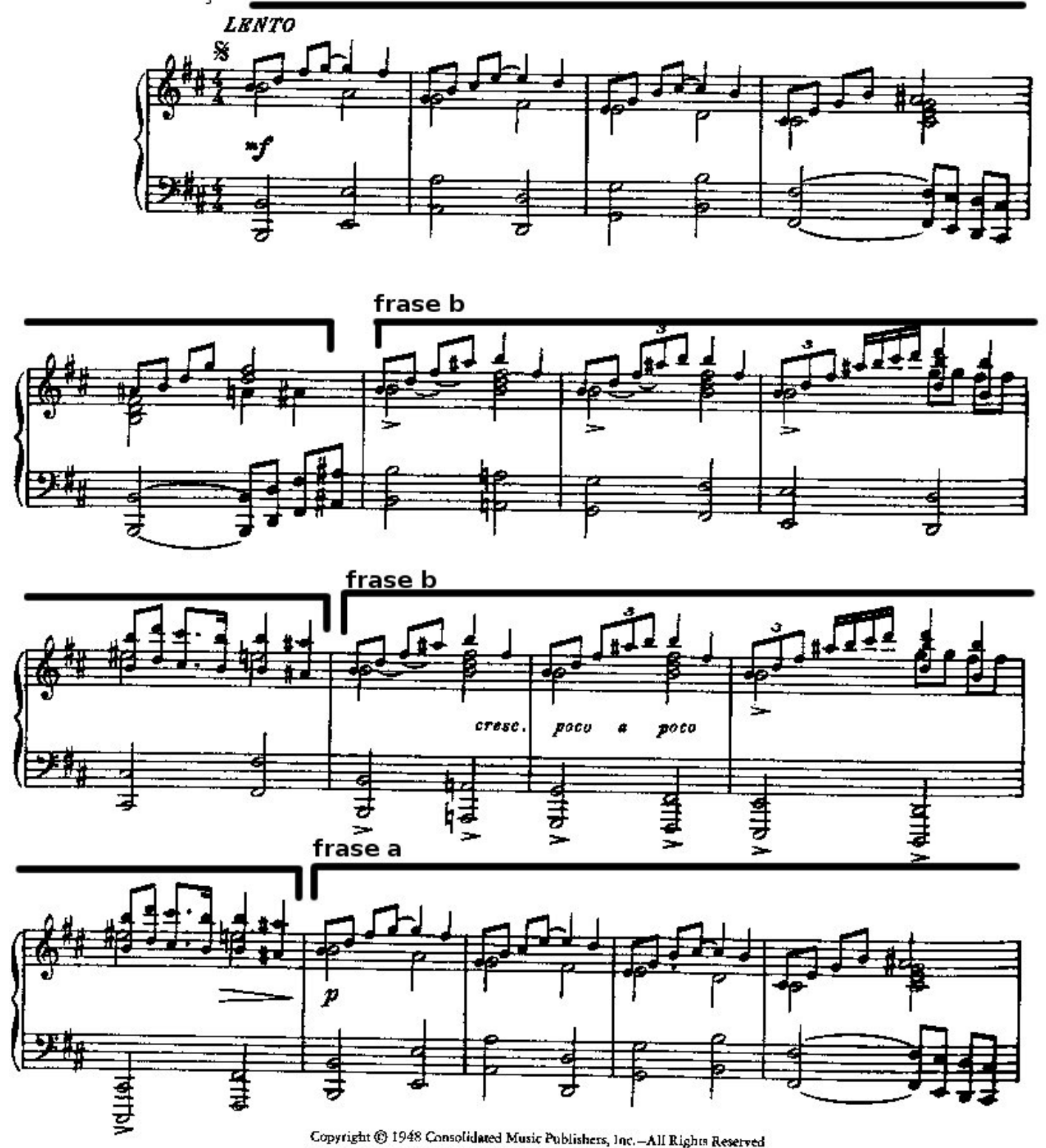

New edition revised by the compase 
DESENVOLVIMENTO
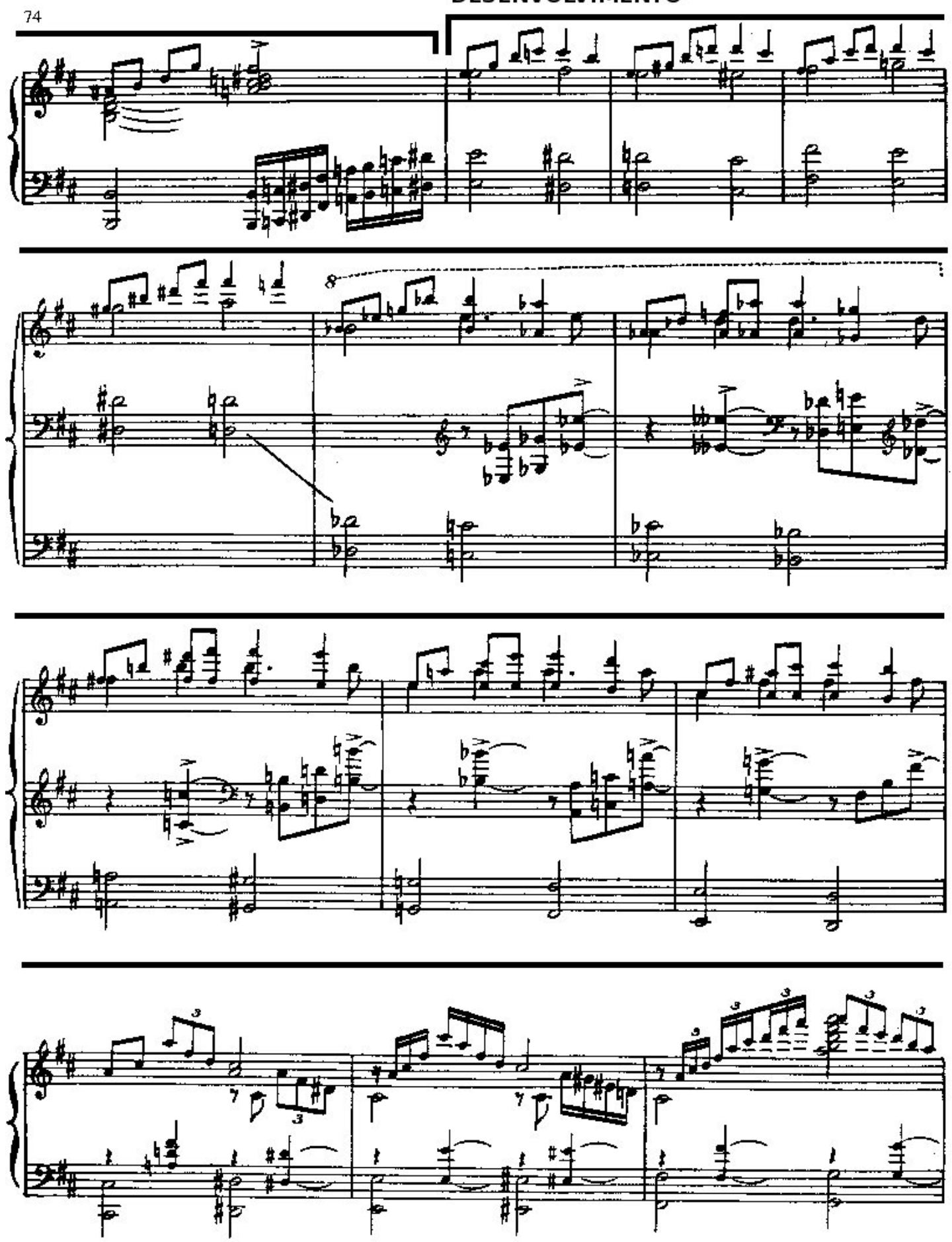

DAPesquisa, Florianópolis, v.3 n.5, p.684-707, 2008. 

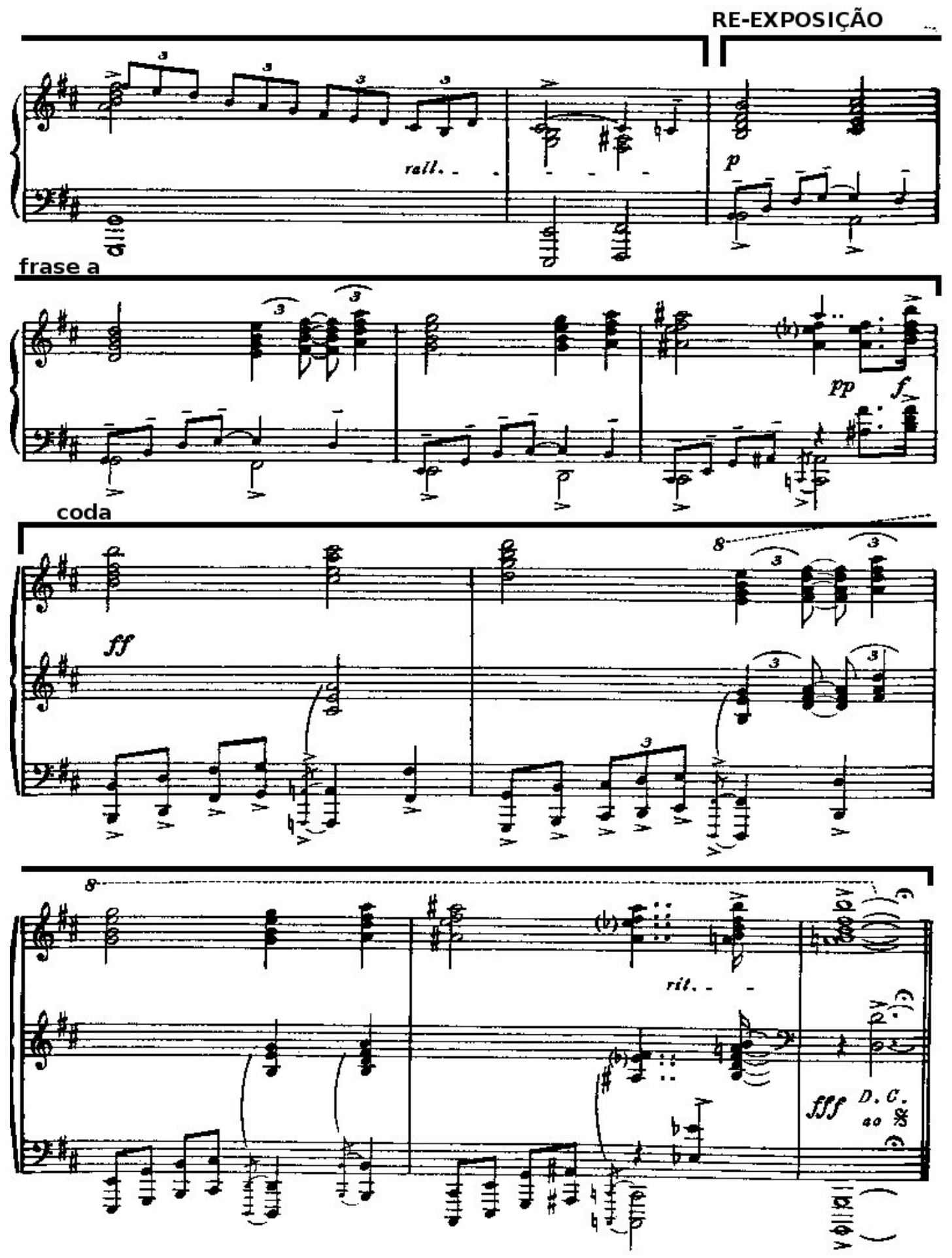

DAPesquisa, Florianópolis, v.3 n.5, p.684-707, 2008. 


\section{Gráfico do foreground da peça completa}
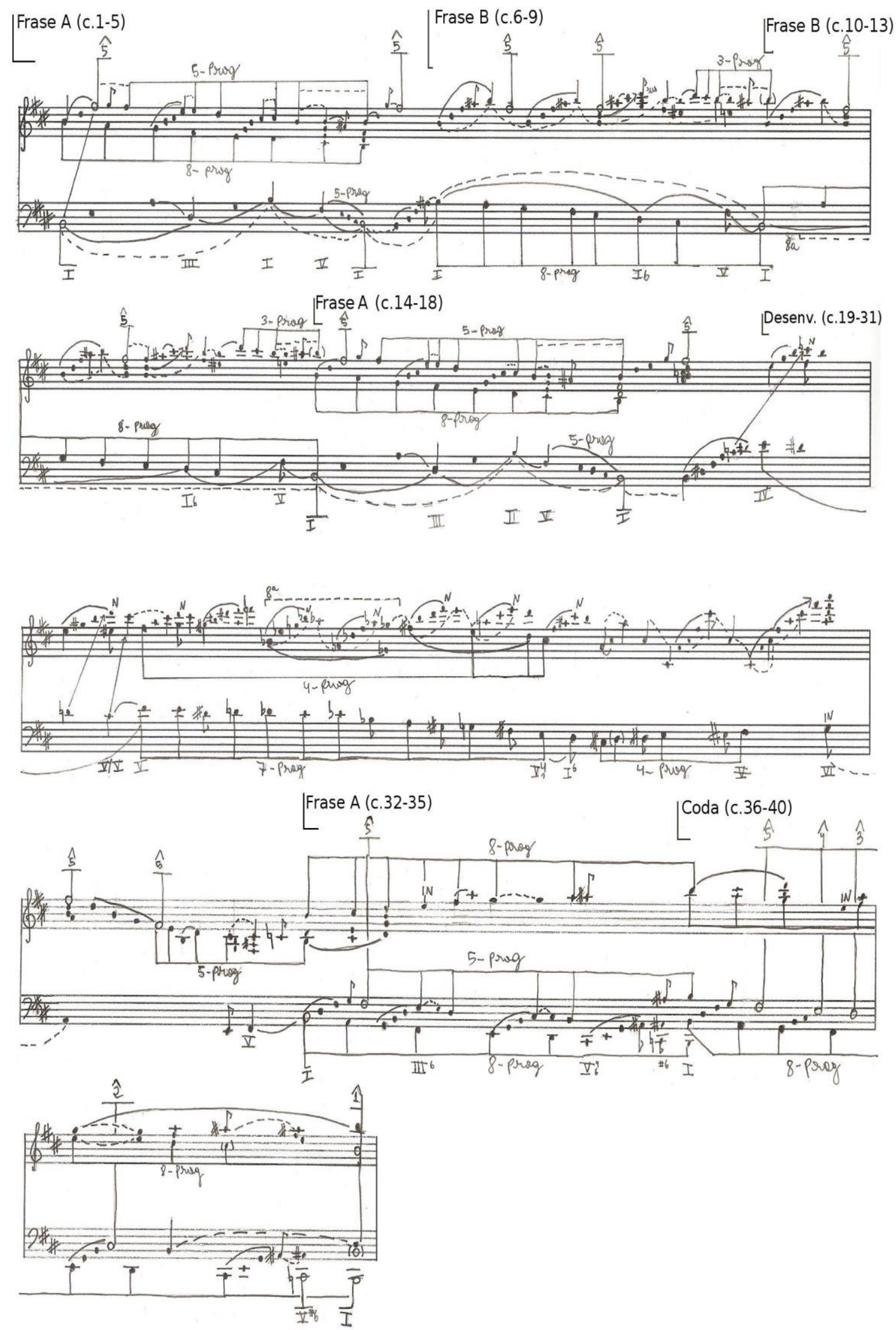

DAPesquisa, Florianópolis, v.3 n.5, p.684-707, 2008. 
Como se pode verificar aqui, as frases A e B são prolongações de si menor, cada uma à sua maneira, usando conduções de vozes diferenciadas e progressões lineares também exclusivas. Vamos agora olhar com mais atenção essas estruturas musicais.

\section{-Exposição}

Frase a (c. 1-5)

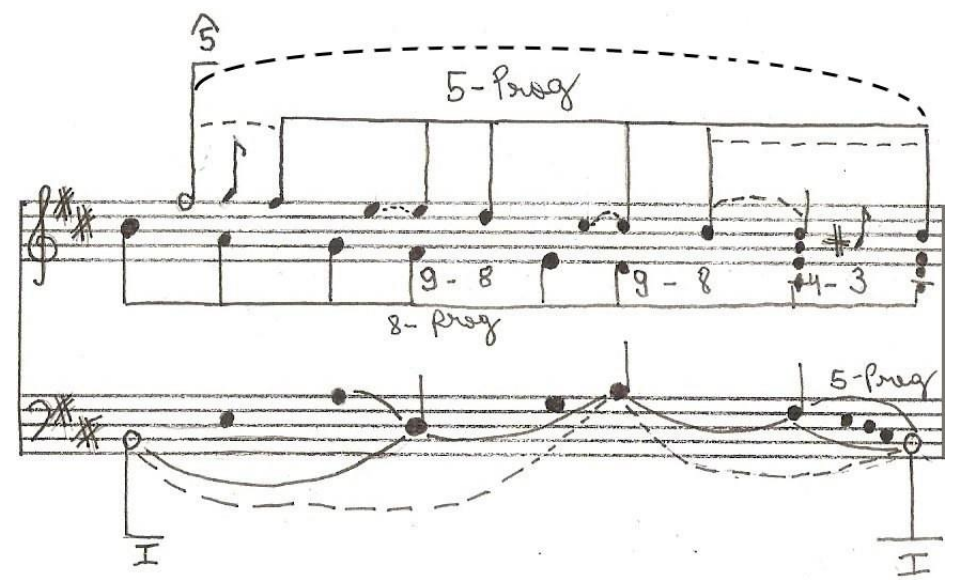

A música inicia com uma ascensão até a primeira nota da urlinie, um arpejo que será o motivo principal de toda a música. Após o arpejo, sol, como nota vizinha de fá\#, suspende a melodia numa dissonância com o lá da voz interior (sétima menor). Villa-Lobos resolve essa dissonância retornando ao fá\#, produzindo, contudo, um intervalo de $9^{\mathrm{a}}$ maior entre as vozes externas (mi e fá\#). A nota mi é entregue ao acorde de ré maior (III) por um arpejo de Lá Dominante. É resolvida, por grau conjunto descendente em ré. Esse procedimento - ascender por arpejo à uma nota da melodia superior, suspendê-la numa dissonância e a resolver no próximo acorde - será o dínamo da frase A em toda a música, inclusive quando essa frase for usada como material do desenvolvimento (c.19-31). As notas sol-si-dó\#-mi, constituem arpejo invertido que sempre conduz a dissonâncias (introduzidas como retardos) dos acordes estruturais da música na frase A. Os acordes produzidos por essas notas arpejadas, juntamente com seus baixos pertencem a um vocabulário harmônico romântico (arpejos de Lá Dominante com $9^{\mathrm{a}}$ [c.2] , Mi menor com $6^{\mathrm{a}}$ maior [c.3] e Fá\# Dominante com Quarta suspensa [c.4]), contudo, a maneira que Villa-Lobos trata essas consonâncias românticas (especialmente no caso do Mi menor com $6^{\mathrm{a}}$ maior na primeira inversão, que antecede o I) nos remete à maneira de Bach tratar as dissonâncias em suas músicas.

As notas alcançadas por esses arpejos e suas resoluções, constroem, na voz superior, uma progressão linear de quinta descendente - de fá\# até si - que prolonga o acorde de Si 
menor no decorrer desse trecho todo. A voz interior, como pode ser visto na redução [c.1-5], prolonga o acorde de Si menor através de uma progressão linear de oitava descendente, do si3 ao si2, formando a escala de Si menor, o que veremos como a melodia do baixo do tema. Essas duas progressões, por estarem deslocadas uma da outra sendo paralelas, possuem um padrão intervalar linear, de dissonância e resolução, como veremos na próxima redução.

A voz inferior também prolonga o acorde de Si menor, através da troca de registro do si e seu retorno no fim da frase. É interessante perceber o arpejo de Si menor construído pelos baixos das notas estruturais, si - ré - fá\# - si.

A frase A é muito semelhante, em estrutura, a Ursatz da peça. Na voz superior, uma progressão linear de quinta descendente, e na voz inferior uma prolongação do I, passando pelas notas de seu arpejo (I -V - I).

Em relação ao contraponto das vozes nessa secção, será útil observar a redução do middleground da mesma.

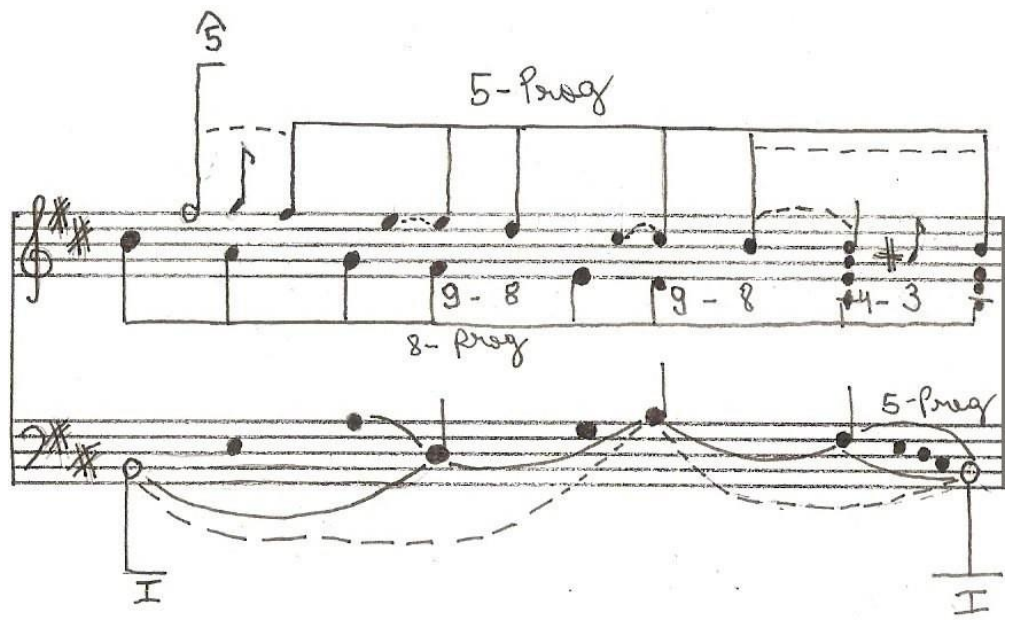

As vozes externas movem-se em direções contrárias, e em diversas ocasiões - como já comentamos - dissonâncias surgem e são resolvidas por grau conjunto descendente. São as nonas dos acordes de Ré maior e Si menor, resolvendo em suas oitavas, e a quarta suspensa de Fá\#, resolvendo em sua terça. Essa resolução da quarta suspensa de Fá\# (si), e o retorno dessa mesma nota no acorde derradeiro da passagem, ocasionam uma condução de vozes oblíqua entre as vozes externas, fazendo transparecer o cuidadoso trabalho de conduções de vozes dessa passagem. Quando todas as vozes formam o Si menor novamente, inicia-se a nova prolongação que ocorre na frase B. 
Frase B (c. 6-9)

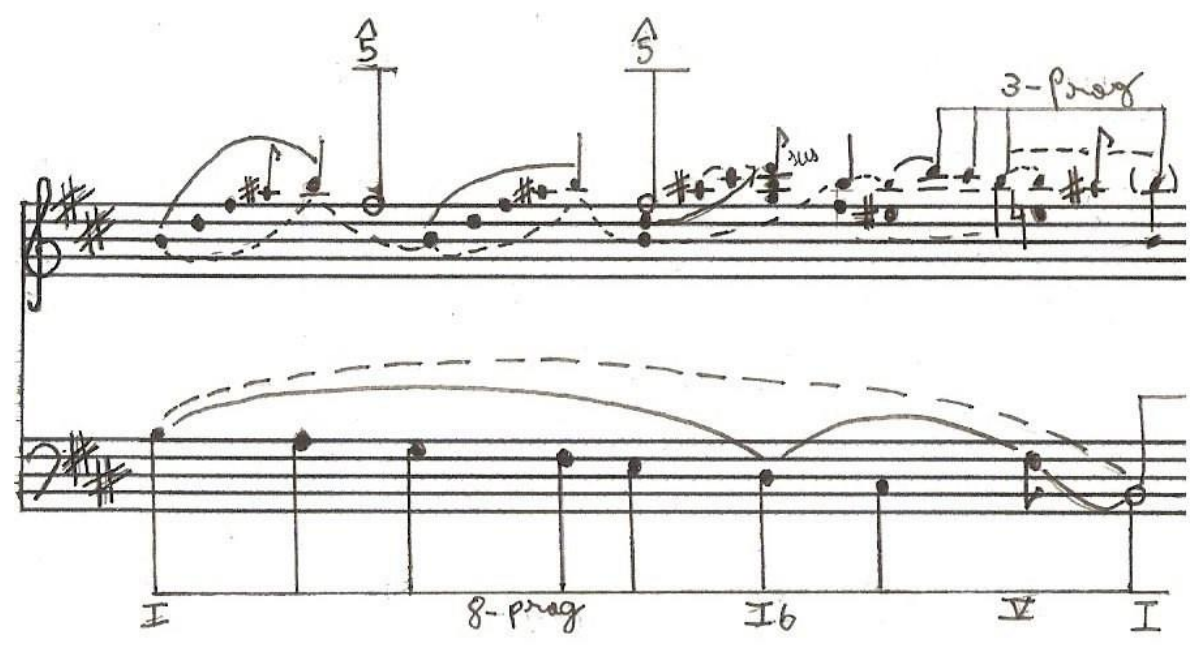

O motivo do arpejo ascendente continua presente nessa frase, contudo, a estrutura das vozes dessa parte é muito diversa da parte A. O arpejo é constituído pelas notas do acorde de Si menor, mais a sensível de si. É repetido, com as mesmas notas (embora com o ritmo diferente) durante toda a frase, ao invés das inversões do arpejo na frase A. E, no lugar da resolução da dissonância por grau conjunto, o mote descendente desse motivo é o salto de quarta justa inferior de si para fá\#, também repetido várias vezes na secção.

$\mathrm{O}$ arpejo prolonga a nota si, trocando-a de registro durante toda a seção. O baixo prolonga a nota si através de uma progressão linear de oitava descendente. Para cada arpejo de Si menor na voz superior, a voz inferior apresenta outra nota do baixo, o que produz novas sonoridades para o mesmo conjunto de notas da voz superior, novos acordes.

$\mathrm{O}$ baixo dos acordes estruturais permanece configurando um acorde de $\mathrm{Si}$ menor, como Bassbrechung. Enquanto as vozes superiores mantém si e fá\# irredutíveis na frase, o baixo é conduzido descendentemente, caracterizando o movimento oblíquo entre as vozes externas. Esse movimento é a estrutura do contraponto da frase B. Quando o baixo alcança, no seu movimento descendente, a nota mi, as vozes superiores arpejam o acorde de Si menor. Quando as vozes configuram o acorde $\mathrm{I}^{6}(\mathrm{c} .8)$, uma das vozes intermediárias se sobrepõe à melodia principal, com a nota ré, numa suspensão do acorde de Si menor. Logo após isso a melodia principal, com si, volta à evidência. Contudo esse ré abre o caminho para uma progressão linear de terça descendente do ré5 ao si4, caracterizando a cadência da frase B. 
O movimento oblíquo das vozes nessa secção ocasiona diversos intervalos, sem um padrão intervalar linear, como a outra secção.

\section{Repetição da frase B (c. 10-13)}

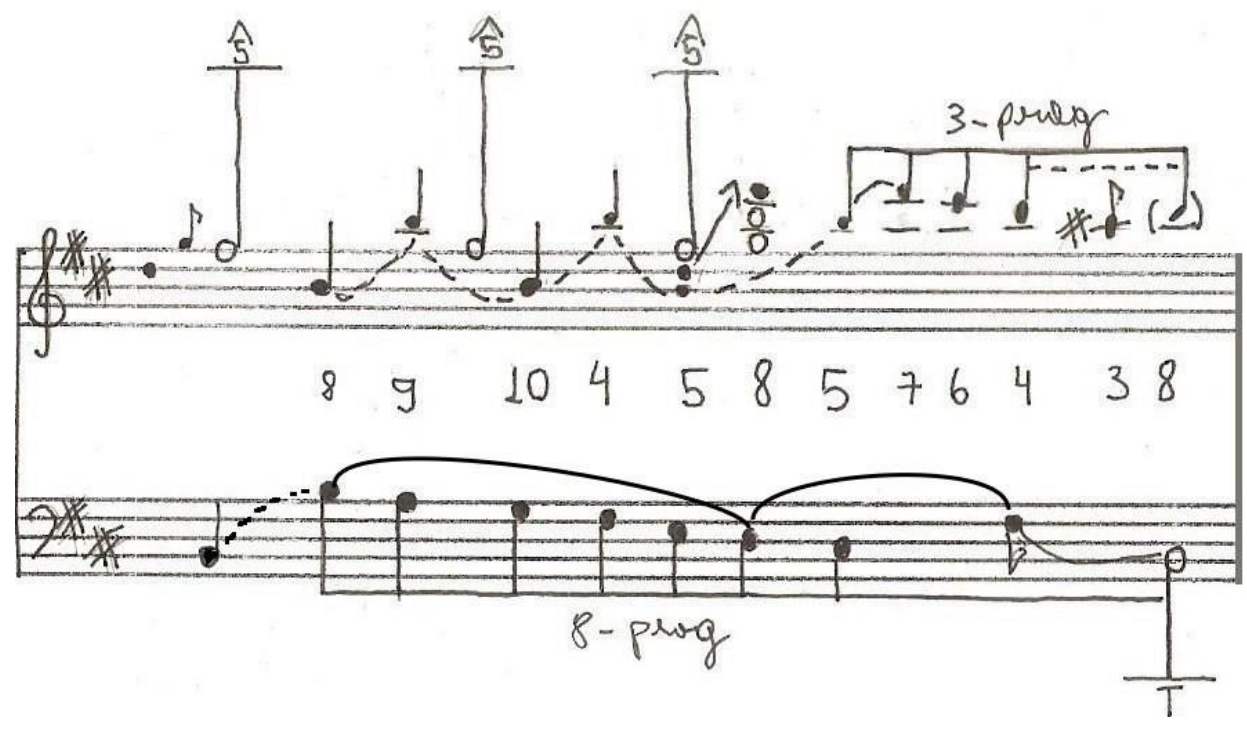

Os eventos contrapontísticos são os mesmos nessa secção, com exceção do baixo que continua descendente, e prolonga o si nessa repetição da frase B, uma oitava abaixo. Fazendo assim, prepara essa voz para a altura que deverá tocar quando a próxima secção iniciar, a frase A.

A dinâmica crescente dessa secção - notada por acentos nas notas do baixo e pelo crescendo na pauta - torna-a uma nova citação da frase B, muito diferente da primeira, com uma outra urgência, que será suprida no final da frase, quando a frase A iniciar, com dinâmica piano, diferente do início da música, quando era mezzo forte. Essa ênfase nas dinâmicas e sua expressividade, como já dissemos no início do trabalho, característica marcante do romantismo, está muito presente nessa obra de Villa-Lobos ${ }^{5}$. O mesmo se pode dizer da exploração de diversos registros, presente nessa seção. Tão importantes são esses elementos românticos nessa obra que uma secção inteira da música foi repetida para ser "modificada" pela dinâmica e para a exploração de registros extremamente graves do piano.

Contudo, a condução de vozes estrutural demonstra o trabalho com consonâncias, dissonâncias e progressões lineares e intervalares aplicado por Villa-Lobos, lugar onde reside

5 Para uma ampla descrição da música romântica para piano, ver Rosen,(2000). 
muito do idioma "bachiano" dessa peça.

\section{Repetição da frase A (c. 14-18)}

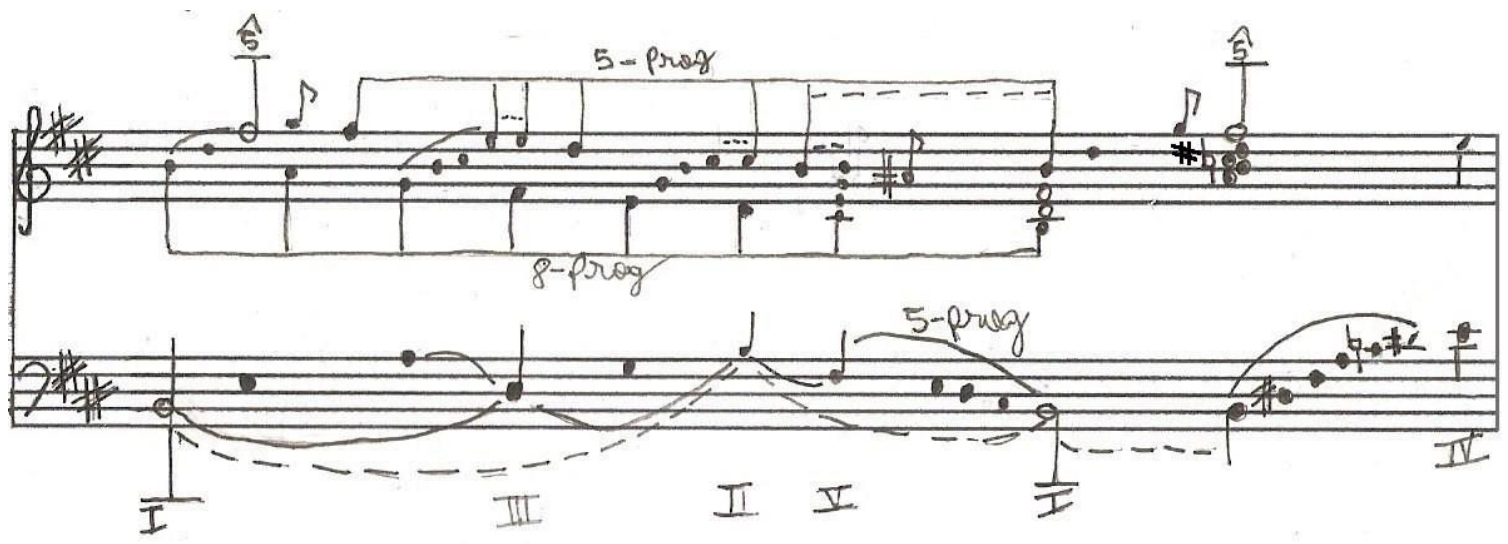

Muito semelhante à primeira aparição dessa frase, difere pela dinâmica piano e pela condução ao desenvolvimento da peça.

Apesar de a voz superior conduzir novamente à fá\# no seu ultimo arpejo, e a voz inferior continuar a prolongar o si, à semelhança da primeira frase $\mathrm{A}$, as vozes internas configuram não mais o acorde de Si menor, mas o acorde de Si Dominante com $9^{\mathrm{a}}$ menor, preparando o início do desenvolvimento, o acorde IV, Mi menor.

O baixo continua a arpejar na cadência da frase A. Contudo, como era de se esperar, o arpejo não é de Si menor, e sim, de Si maior.

\section{Desenvolvimento(c.19-31)}
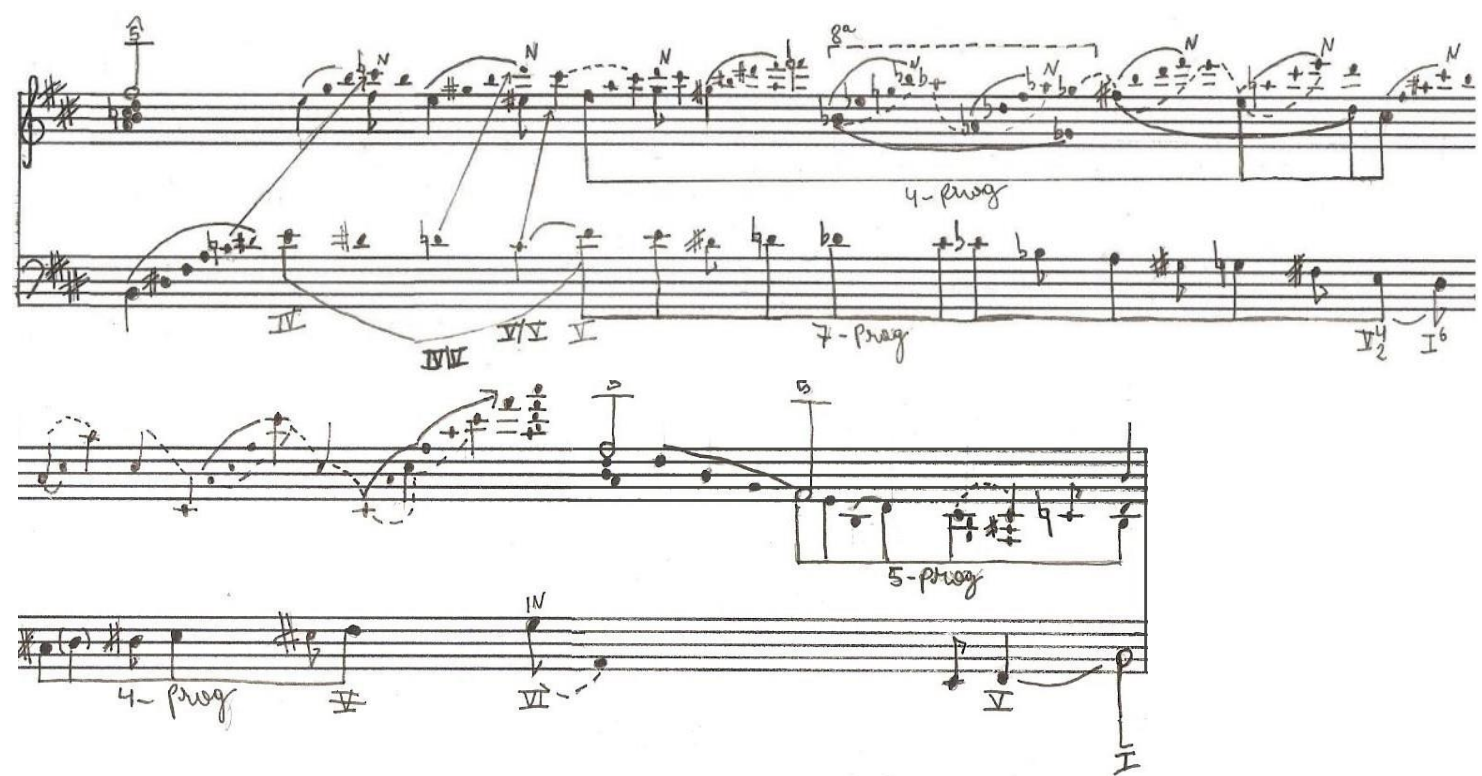

DAPesquisa, Florianópolis, v.3 n.5, p.684-707, 2008. 
O motivo do arpejo ascendente aqui é levado mais longe. Inicialmente, o dó introduzido pelo arpejo de Si Dominante com $9^{a}$ menor é transferido para a melodia, bem como o ré, como mostra o gráfico. Chegando à nota fá\# no baixo, inicia-se uma progressão linear que prolongará o $\mathrm{V}$ de Si menor. A progressão de sétima descendente até a nota mi é acompanhada por uma progressão linear de quarta na voz superior de fá\# até a nota dó\#. As duas progressões terminam sobre um acorde de Fá\# dominante na terceira inversão, que resolve no $\mathrm{I}^{6}$.

A ocorrência simultânea dessas duas progressões (seus inícios e fins), sua localização no contexto da peça, a resolução das suas notas no acorde estrutural de Si menor e a mudança na direção do movimento das vozes após seu fim atestam o prolongamento do V de Si menor; ocorre aqui, portanto, uma tonicização em Fá\#. Há, inclusive, uma progressão linear de terça descendente nas vozes inferiores de lá\# (enarmonia de sib) até fá\# (enarmonia de sol $b$ ), enfatizando a importância dessas duas notas no contexto dapassagem.

Com a liberdade característica dessa seção, uma seqüência de dominantes estendidas conduz a música de Mib Dominante na segunda inversão (c.23) até Ré Dominante na primeira inversão (c.26). O dialogo entre as vozes intermediárias e a melodia principal foi muito semelhante ao que ocorreu na frase A da exposição. O arpejo do acorde dominante conduzia a nota do início do arpejo uma oitava acima. Quando essa nota era alcançada, o acorde sob ela mudava (para o próximo dominante) tornando essa nota, antes consoante, uma nota vizinha a ser resolvida por grau conjunto descendente.

Após o Ré Dominante, o acorde Fá\# Dominante na terceira inversão soa, resolvendo no acorde de Si menor na primeira inversão, iniciando um outro movimento das vozes e uma seção pré-cadencial do desenvolvimento.

Dentro do desenvolvimento, há uma secção onde a imitação - procedimento característico de Bach - toma lugar de destaque na composição (c.22-30), exigindo a introdução de mais um pentagrama no sistema. Trata-se de uma imitação não-literal, que replica o motivo gerador da imitação na curva da melodia, mas não com as mesmas alturas, dando sustento a harmonia das dominantes estendidas.

Nos compassos 28-29, a imitação se da na clave de sol, em vozes diferentes dentro da mesma pauta. 
Essa seção pré-cadencial (c. 28) é crescente, do ponto de vista rítmico e melódico. As figuras rítmicas da melodia vão ficando mais curtas, enquanto as frases construídas por elas vão crescendo e alcançando o registro mais agudo até o ápice da frase, o acorde Sol maior $\operatorname{com} 7^{\mathrm{a}}$ maior e $9^{\mathrm{a}}$. Enquanto isso, o baixo descendente costura o movimento contrário com a voz superior. Esse procedimento enérgico acumula uma urgência de relaxamento que será obtido na cadência do desenvolvimento, quando um arpejo descendente em tercinas sobre as notas do acorde o acorde Sol maior com $9^{a}$ maior e $9^{a}$. Após essa parte da cadência, com acento debussyano, o acorde de Mi menor com $6^{\mathrm{a}}$ e Fá\# Dominante, entregam, com um rallentando, a música à sua re-exposição.

Nesse momento da obra, através do arpejo, o compositor levou a peça a um outro registro, mais grave, onde acontecerá a re-exposição. Pelo arpejo descendente, o fá\# da urlinie desce uma oitava e dele parte uma progressão linear de quinta descendente até si, onde acordes tomaram o registro da melodia, que se ouvirá na re-exposição, na clave de fá. Pelo fato de ocorrerem progressões lineares paralelas entre as vozes, o padrão intervalar linear 7-6 entre as vozes foi recorrente.

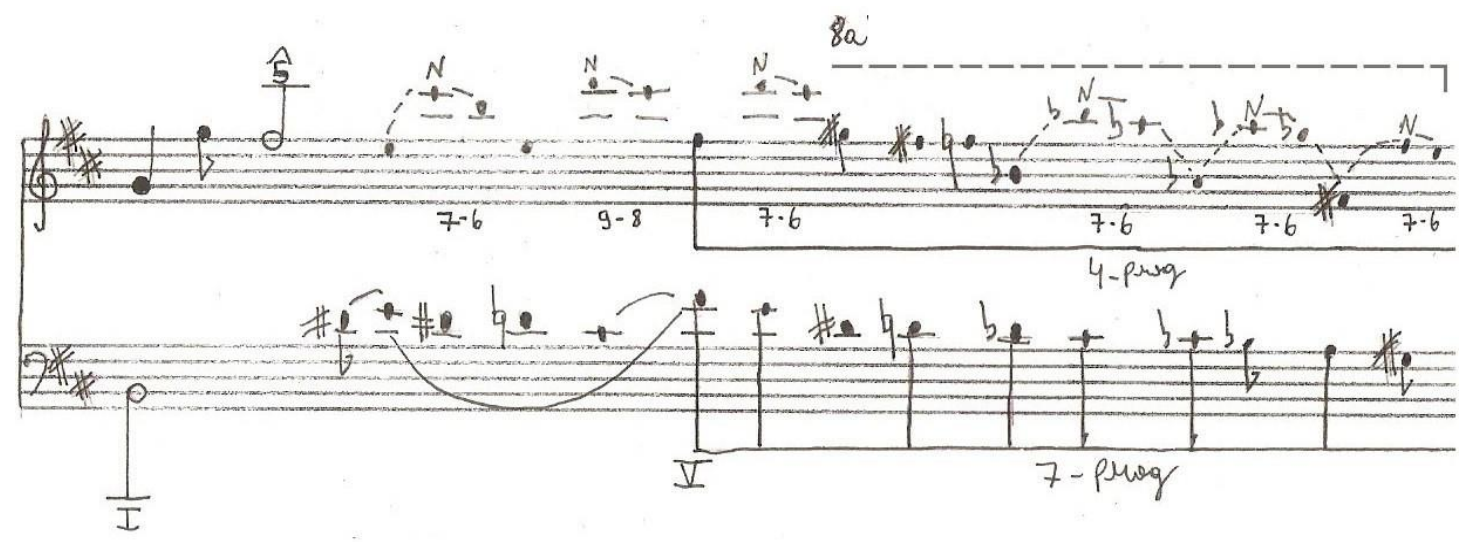



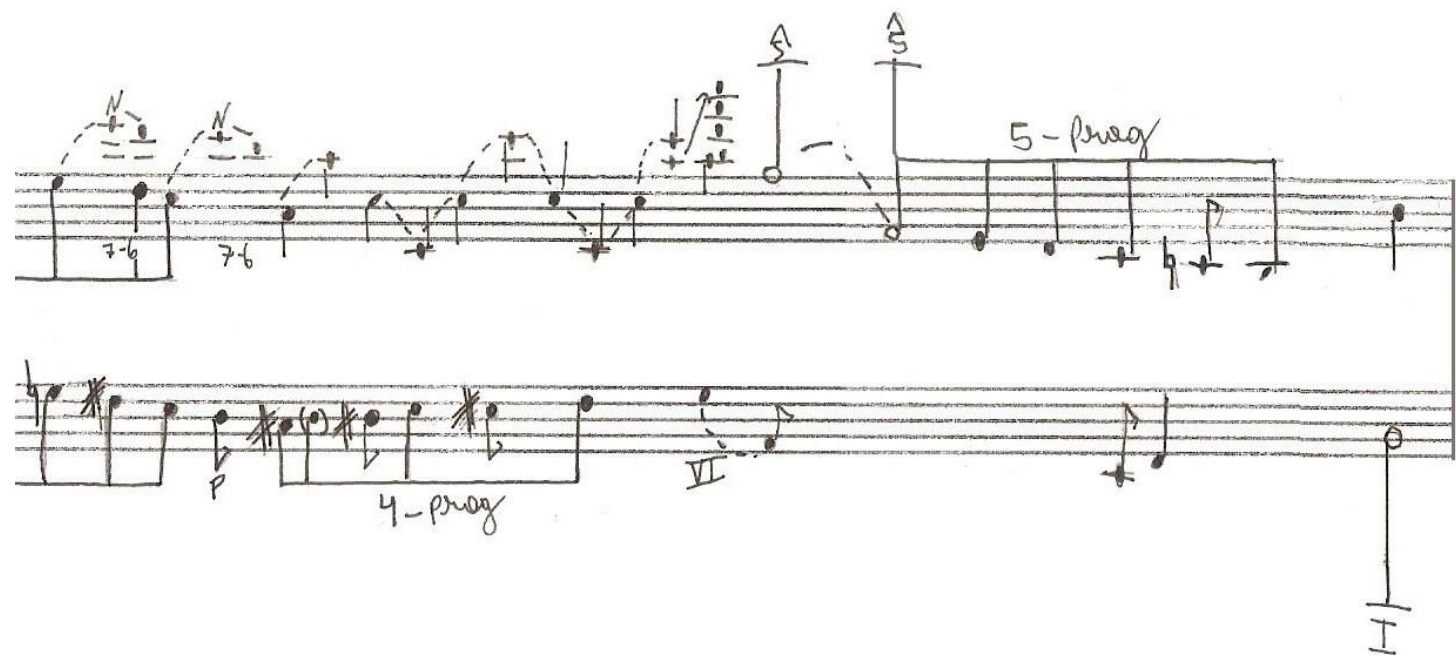

-Re-exposição

Frase A (c.32-35) e Coda (c.36-40)

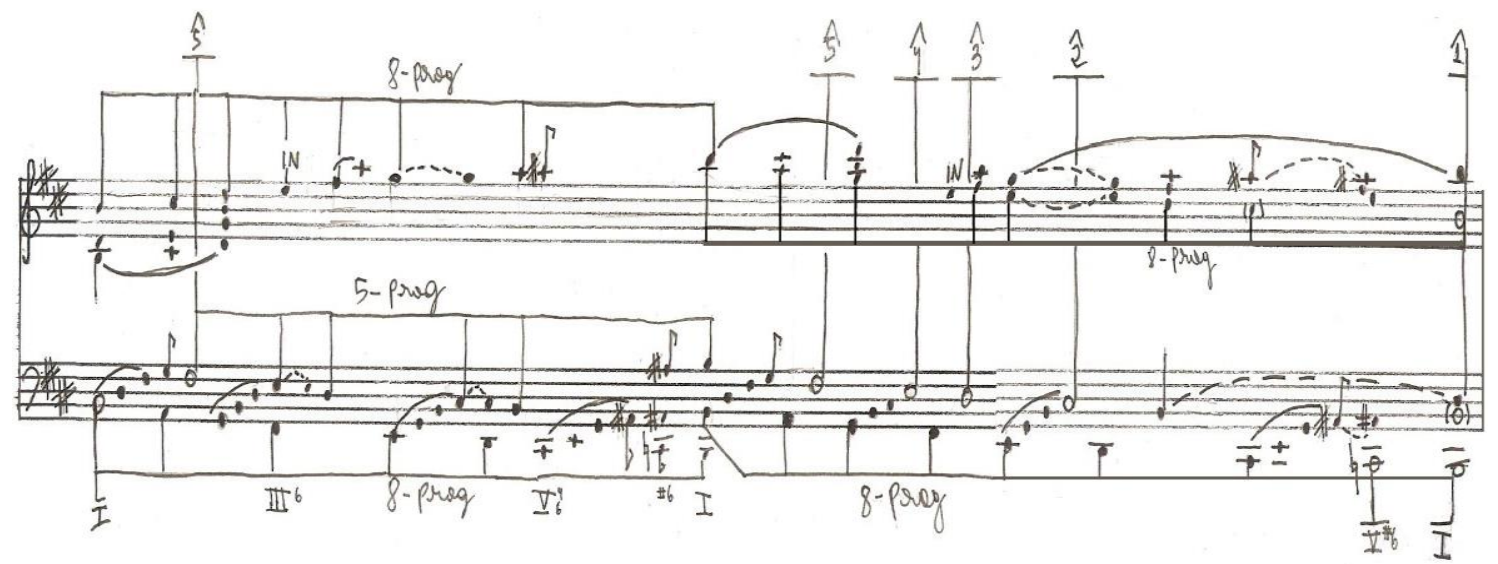

Na re-exposição da frase $\mathrm{A}$, uma nova textura da música é apresentada. Além das vozes dos arpejos e baixo, acordes são montados na clave de sol, ocupando o registro que antes era da melodia.

A melodia, os arpejos e a urlinie são apresentados em uma tessitura mais grave, na clave de fá, sobre a voz mais grave que desce, a exemplo da frase B da exposição, duas oitavas através de duas progressões lineares de oitava descendente. Também a exemplo da frase B, a dinâmica inicial dessa secção é um súbito fortissimo logo após o fim do desenvolvimento, em pianissimo.

Os dois prolongamentos de Si menor nessa secção são ocasionados por progressões lineares de oitava descendente nas duas vozes externas. 
Como pode ser visto na redução anterior, na primeira metade desse trecho, as vozes externas desenvolvem progressões lineares de oitava em direções opostas, em movimento contrário, a voz superior ascendentemente e a inferior descendentemente. Já na segunda metade, as duas progressões lineares de oitava são paralelas, apesar do ritmo delas ser diferente, ambas são descendentes, fato que ocasionaria um problema de condução de vozes. Contudo, a voz superior desenha progressões lineares ascendentes que propiciam esse paralelismo entre as progressões de oitava descendente.

A urlinie, agora presente na clave de fá, na repetição da frase A, desce pela ultima vez encontrando o primeiro grau de Si menor. O bassbrechung encontra seu V com sexta aumentada, recurso utilizado algumas outras vezes no decorrer da música, mas que agora, pela força na interpretação e pela localização na música é estrutural e antecede o Si menor, que é tocado como grand finale, em molto fortissimo, mostrando o grande acorde da música, resumo da mesma.

\section{Conclusões}

Pudemos observar que, através da condução das vozes, da inserção e resolução de dissonâncias, do prolongamento de acordes, de recursos de imitação motívica e do discurso harmônico tonal, os meios pelos quais o compositor constrói sua música à maneira de Bach ficam mais claros. Contudo, esta obra pertence aparentemente muito mais a uma estética romântica neoclássica que ao idioma nacionalista de Villa-Lobos. Onde está o nacional aqui? Ora, aquele nacional auto-evidente das suas primeiras obras não está presente aqui. O que podemos afirmar é que está presente aqui o "nacionalismo eclético" de Villa-Lobos (Béhague, 1994), através da referências sutis ao mundo do choro, particularmente à seresta. A seresta (serenatas) se caracteriza pela melodia cantabile romântica entrecortada por frases das

cordas graves do violão. É um elemento presente nesta obra. No entanto, o que é mais notável são as idéias musicais, elas mesmas ao mesmo tempo previsíveis (em termos da estética cadencial romântica) e muito originais. Sem dúvida, Villa-Lobos foi um grande criador de idéias musicais, no sentido schoenbergiano, e com elas desenvolveu seu estilo único (SILVA, 2006). 


\section{REFERÊNCIAS:}

CADWALLADER, Allen \& GAGNÉ, David. Analysis of Tonal Music: A Schenkerian Approach. New York: Oxford University Press, 1998.

CADWALLADER, Allen \& GAGNÉ, David. Analysis of Tonal Music: A Schenkerian Approach - Student Workbook to Accompany. New York: Oxford University Press, $2006 .$. BARROS, C.Paula. O Romance de Villa-Lobos. Rio de Janeiro: A Noite, 1950. AMATO, Rita de Cássia Fucci. Momento brasileiro: reflexões sobre o nacionalismo, a educação musical e o canto orfeônico em Villa-Lobos. Revista Electrónica Complutense de Investigación en Educación Musical, Volumen 5 Número , 2008. Disponível em <http://www.ucm.es/info/reciem/v5n2.pdf>. Acessado em 15/07/2008.

BÉHAGUE, Gerald. Heitor Villa-Lobos: the search for Brazil's musical soul. Austin: University of Texas Press, 1994.

CALDAS, Sérgio Eduardo da Silva. Elementos necessários à representação descritivas de partituras : um estudo com as Bachianas Brasileiras n.1, 2 e 4 de Heitor Villa-Lobos. Monografia apresentada ao Curso de Ciência da Informação com habilitação em Biblioteconomia da PUC de Campinas, 2007.

CHATEAUBRIAND, Mônica D.P.E. Villa-Lobos, Tom Jobim, Edu Lobo: o terceiro vértice. Dissertação de mestrado. Programa de Pós-Graduação em História, Política e Bens Culturais. Centro de Pesquisa e Documentação de História Contemporânea do Brasil. Rio de Janeiro: FGV, 2006.

GUÉRIOS, Paulo Renato. Heitor Villa-Lobos e o ambiente artístico parisiense: convertendose em um músico brasileiro. Mana vol.9, n. 1, Rio de Janeiro, 2003.

JARDIM, Gil. O Estilo Antropofágico de Heitor Villa-Lobos. São Paulo: Edição Philarmonia Brasileira, 2005.

LISBOA, Alessandra Coutinho. Villa-Lobos e o canto orfeônico: música, nacionalismo e ideal civilizador. Dissertação de mestrado apresentada ao Programa de Pós-

Graduação em Música do Instituto de Artes da UNESP, 2005. Disponível em<http://www.ia.unesp.br/pos/stricto/musica/teses/Alessandra_Lisboa.pdf >. Acessado em 16/07/08.

MARIZ, V. Heitor Villa-Lobos, Compositor Brasileiro. Rio de Janeiro: Divisão Cultural do Ministério das Relações Exteriores, 1949. 
NEVES, José Maria.Música Contemporânea Brasileira. São Paulo: Ricordi, 1981.

PEPPERCORN, L. M. Villa-Lobos Collected Studies. England: Scholar Press, 1992.

ROSEN, Charles. A geração romântica. São Paulo: Edusp, 2000.

SALZER, Felix. Structural Hearing: Tonal Coherence in Music. New York: Dover, 1962.

SALZER, Felix \& SCHACHTER, Carl. Counterpoint in Composition: the study of voice

leading. New York: McGraw-Hill, 1969.

SILVA, Francisco Pereira da. Villa-Lobos. São Paulo: Ed. Três, 2003.

SILVA, José Ivo da. Os Estilos e as Idéias em Villa-Lobos. Anais do Simpósio de

Pesquisa em Música 3. UFPR: 2006, p. 81-87.

SCHENKER, Heinrich. Free Composition. New York \& London: Longman, 1979.

VILLA-LOBOS, Heitor. Educação Musical. Boletim Latino Americano de Música, Montevidéu, p. 495-588, 1946. 